\title{
'Mama-mama' in Papua and the Access to Market
}

\author{
Ransta L. Lekatompessy ${ }^{1}$ \\ ${ }^{1}$ Faculty of Social and Political Sciences Universitas Musamus
}

\begin{abstract}
The spearhead of people's economy in Papua is local traders which usually called as 'mama-mama', they try to increase family economy in Papua. The struggle among woman to seek basic necessities for their family needs serious attention from the government, particularly how to access traditional market as the place for them to sell the products of agriculture products or handcrafts such as noken and others. This article describes the existence of 'mama-mama' as women who have dual role in family, and also discusses social movement of mama-mama in Papua to access traditional market through 'Solidaritas Pedagang Asli Papua (SOLPAP)'. Besides, this article also discusses government role and the existence of social movement in implementing empowerment among mamamama Papua regarding the training how to manage agriculture products and family coaching.
\end{abstract}

\section{Keywords: woman in Papua, social movement, and empowerment}

\section{Introduction}

People's economy basically is an economic system which based on the power of people's economy. According to Mubyarto, he stated that "people's economy is a democratic economy that aims to people's prosperity"[1]. The sector of economic development has an important role for the nation prosperity. In addition, national development is aimed to achieve the community living standards in the level of prosperity, health and education. The indicators of economic development are the increase of economic growth, the increase of income per capita, the greater working opportunity and the decrease of unemployment and poverty.

The spearhead of people's economy in Papua is local traders which usually called as 'mama-mama' and they try to increase family economy in this time. The role of women in providing basic necessities in Papua is not a new matter. Moreover, the dual role among women in Papua is an obligation of women in providing basic necessities for their family. Unfairness that happened to Papuan women caused by adat. According to Petrus Tekege "women controlled by men, women are seen as mere possessions of men" [2]. The community in Papua describes that the role of man and women is quietly different. Man has role cutting trees and splitting tree trunks and the next job such as pounding and processing sago shall be carried out by women. Generally, women shall provide foods and capture fish in the sea or river. Meanwhile, men are usually busy with clan war.

Patriarchy culture which is continuous grow and persistent in Papua community until nowadays causes women being on the front line to fight for family survival. Women sell some products in the market such as products which have been processed or planted, they also resell some products which have been bought from other seller with hopes they will get profit.

The struggle of mama-mama Papua in traditional market who is fight for family economy, besides other duty such as working in the field and handling children, is not easy to imagine. This problem caused by the difficulty to access the market and stalls in traditional market which are still dominated by entrant traders, instead origin people [3].

Papua as an area that is rich in natural resources causes a lot of extractive activities to occur in the area, which has an impact on environmental damage.

Most of mama-mama chooses selling the products in the streets around the market without any roofs on a dirt road which the condition is dusty and muddy during rainy season. This mama-mama display the product grounded with sacks, plastics or without any sockets. The commodity is local products such as chili, tomatoes, water spinach, banana, tubers, areca palm and betel as contact tools to strengthen communication among origin people in Papua and other handcrafts such as camshaft and others.

* Corresponding author: ranstalewina@gmail.com 
Market in Papua is a social room which reflects local society and its problems. The main problem is economic access which is reflected by the struggle of mama-mama Papua. Meanwhile, market may solve some problems such as health, education, local politics and domestic violence. he problem of access to the market is a classical problem until nowadays. Some efforts conducted by Solidaritas Pedagang Asli Papua (SOLPAP) such as solidarity for mama-mama trader in Jayapura-Papua was carried out since 2008 [4]. This social movement has an effort to pursue market development for mama-mama. In addition, some meetings with city government, DPRD and DPRP have been organized.

The effort of economic development and even distribution of development result in order to increase people income shall be perceived all the community level. However, the problem of economic development still occurs in Papua Province is belows:

1. People's economy development to support family income based on adat community rights is not effective;

2. The implementation of Village Development Strategic Plan (RESPEK) to accelerate the development of village productivity is not effective

3. The development of local superior commodity which has market potential both national and international is not optimum;

4. The development of local tourism industry is not integrated with various natural and cultural potential which may increase income for adat community and local people;

5. The protection of adat community rights toward culture and its results is not maximum which is suppose increase the income of local community;

6. The role of adat community and religion institutions in developing people's economic and income is not optimum.

7. The lack of concept or action plan of people's economic development which is more comprehensive and integrated ranging from production to marketing stage which leads to market needs and requirements [5].

All problems of economic development in Papua, particularly people's economic development is to support family income. Further discussion will be focused on mama-mama Papua as people's economic activator in order to achieve the access to traditional market in Papua.

\section{Methodology}

This article uses a literature study method with an observational approach to social issues related to the topic of writing. The study of literature is theoretical studies, references and other scientific literature related to culture and values and other norms that develop in the social situation of research [6]. Therefore, this writing, quoting from various sources of books and journals, and making observations of Mama-mama in Papua.

\section{Discussion}

The development of people's economy in Papua for origin people of Papua requires serious attention from the government as decision maker. In addition, the province government has strategic stages in order to fasten the development, such as the development of small and traditional economic in isolated territory which is stipulated in synchronization of Medium Term Development Plan (RPJM) between central government and Papua province in 2013-2018 [7]. This strategic stage is aimed to provide opportunity for origin people of Papua to increase family economy and equality as well as creativity which is able to compete with other regions in Indonesia.

Special Autonomy Regulation, article 42 paragraph 1 stipulates that "economic development is based on democracy and carried out by giving the adat community and/or the local people the broadest possible opportunity", next paragraph stipulates that investors investing within the territory of the Province of Papua must acknowledge and respect the rights of the local adat community". Meanwhile, the last paragraph of article 42 stipulates that "providing the opportunity to do business as intended in paragraph 1 , is carried out in the framework of empowering the adat community in order for them to be able to play the broadest possible role in the economy" [8].

The follow up of Special Autonomy Regulation is the enactment of Special Regional Regulation (Perdasus) Number 25 year 2013 article 11 paragraph 1c which regulates concerning the funding of people's economy development which 20 percent shall be allocated to fund the credit of people's economy business, revolving fund, subsidy of nine basic necessities (sembako) and superior commodity development [9].

Empowerment and participation needs serious attention in development process. Empowerment and participation, according to Paul is a potential strategy in order to increase economy, social and culture transformation. In addition, the best way to solve development problem is by encouraging entrepreneurship spirit in the community, bet-your-company, competition, finding competition spirit and innovation through community participation [10].

In general, empowerment and participation among women in Papua carried out by training and coaching which later, it may increase the quality and quantity of natural resources processing, skill and handcraft, as well as family coaching. The development of local resources potential such as areca nut, camshaft or other souvenirs, red fruits, local vegetables is continuously attempted. Empowerment is aimed to increase community economy productively, therefore people may obtain greater added value and income. The effort to increase capability in order to result added value is aimed to improve access in these matters: the access to resources, the access to technology, the access to market and the access to demands.

The government of Papua Province cooperates with the government of New Zealand that is United 
Nation Development Program (UNDP) Indonesia and International Labor Organization (ILO) through the implementation of 3 (three) components of People Centered Development Program by conducting Sustainable Livelihood Development Institutionalized for adat community in Papua. The approach used in this cooperation is providing term of reference model which implements right process to identify and design intervention in developing local competitive products and micro business belonging to adat community in Papua. Mama-mama Papua as the actor of small and micro business are engaged in developing small and micro business of Papua by increasing the capacity and skill regarding business management, domestic financial, access to micro funding institution and marketing as well. In district level, some services of business development has been conducted through training and mentoring of qualified and sustainable business development for 504 Small and Micro Business original in Papua (65 percent is business women) which belongs productive economy by producing local commodity [11].

The access of origin people in Papua, in this case women and mama-mama, to market still becomes the main problem in the territory of Papua and West Papua. The biggest challenge which inhibits economy development and women prosperity in Papua is geographic condition which is difficult to reach, bad infrastructure of bridge and market and the transportation of land, sea and air which is expensive. Besides, the condition such as the road which is bad, the location of market which is far from their village, river without bridge, hilly areas, small islands without any infrastructure to the district, city or regency, all of this condition is great challenges for women in Papua.

Most women traders in Papua in some districts are complaining all challenges and obstacles in accessing to traditional market. The main challenges they face are: table to display the product is dominated by traders of non-Papua ethnic, the location of permanent market developed by local government is less strategic, the lack of potential buyers in new district since people are going to city or district to do shopping, bad management in the market which causes conflict in the distribution of display table.

A hard and long struggle among business woman in Papua through SOLPAP regarding the access of mamamama toward market is getting good result. It is shown by the development of 15 people's market in Papua and West Papua. This development of people's market is the evidence of government's partiality to the community as well as the reflection Nawacita programs. One of the concepts of mama-mama Papua is the cultural market which based on local wisdom by giving priority to community empowerment mainly among woman and children. This market is located in the middle of Jayapura, it has four floors which funded by Corporate Social Responsibility from Pertamina and PT. Perusahaan Gas Negara about Rp. 35 trillion. This market hopefully becomes the centre of distribution or induk market and the centre of transaction of products which are generated from earth, meat and fish from 15 districts/cities in Papua ${ }^{12}$.

\section{Conclusion}

Patriarchy culture which is still powerfully implemented in the community is the obstacle for women in Papua in empowering their capacity. Women in Papua is not merely as mother for their children but also the backbone of family economy which is indirectly they are the actor of economy in Papua. As the actor of economy in Papua, therefore, the empowerment of mama-mama in Papua and access to the market shall be the priority program of development in district/city in West Papua and Papua Province. The presence policy is aimed to manage the access for mama-mama to the market which is equalized by the allocation of stalls between mama-mama with the new comer or medium entrepreneur. The coaching is carried out toward the implementation of agriculture, farming, small industry based on local wisdom and sustainability. By working mothers in Papua will cause reduced extractive activities, because the work of mothers in Papua is not extractive so as to reduce environmental damage.

\section{References}

1. Mubyarto, Reformasi Sistem Ekonomi: Dari Kapitalis Menuju Ekonomi Kerakyatan (Aditya Media, Yogyakarta, 1999).

2. T. Petrus, Perempuan Papua (Sinar Harapan, Jakarta, 2007).

3. I. N. Suryawan, Tak Cukup Bagi Kami Meratap: Kami Harus Berjuang Kemandirian Mama-Mama dalam Dinamika Pemekaran di Tanah Papua, hal. 150-162 (2016).

4. T. C. Penyusunan, P. Rencana, P. Daerah, R. P. Jangka, T. L. Negara, T. Lembaran, Gubernur papua (2013).

5. Sugiyono, Metode Penelitian (Alfabeta, Bandung, 2012).

6. R. P. Papua, Sinkronisasi rencana pembangunan jangka menengah pusat dan daerah serta arahan kebijakan untuk rpjmd provinsi papua 2013-2018 (2018).

7. P. D. Khusus, O. Khusus, Gubernur papua (2013).

8. KEPRES, Presiden republik indonesia, no. 1, hal. 14 (1980).

9. H. Harry, Strategi Pemberdayaan Masyarakat (Humaniora Press, Bandung, 2010).

10. A. Papua, Pelembagaan Pembangunan Mata Pencarian yang Berkelanjutan Pengembangan Usaha Mikro dan Akses ke Lembaga (2013).

11. P. H. Masyarakat, Siaran pers, no. 5, hal. 1-2 (2014). 